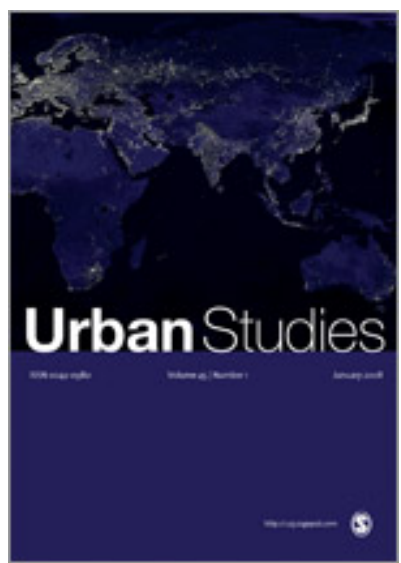

\title{
The time-spaces of austerity urbanism: narratives of 'localism' and UK neighbourhood policy
}

\begin{tabular}{|r|l|}
\hline Journal: & Urban Studies \\
\hline Manuscript ID & CUS-587-19-07.R2 \\
\hline Manuscript Type: & Article \\
\hline $\begin{array}{r}\text { <b>Discipline: Please select a } \\
\text { keyword from the following } \\
\text { list that best describes the } \\
\text { discipline used in your paper.: }\end{array}$ & Geography \\
\hline $\begin{array}{r}\text { World Region: Please select } \\
\text { the region(s) that best reflect } \\
\text { the focus of your paper. }\end{array}$ & \\
$\begin{array}{r}\text { Names of individual countries, } \\
\text { cities \& economic groupings } \\
\text { should appear in the title } \\
\text { where appropriate.: }\end{array}$ & Western Europe \\
\hline $\begin{array}{r}\text { Major Topic: Please identify } \\
\text { up to } 5 \text { topics that best } \\
\text { identify the subject of your } \\
\text { article.: }\end{array}$ & Community, Governance, Local Government, Policy, Poverty/Exclusion \\
\hline $\begin{array}{r}\text { You may add up to } 2 \text { further } \\
\text { relevant keywords of your } \\
\text { choosing below:: }\end{array}$ & Austerity, Temporality \\
\hline
\end{tabular}

\section{SCHOLARONE \\ Manuscripts}




\title{
The time-spaces of austerity urbanism: narratives of 'localism' and UK neighbourhood policy
}

\begin{abstract}
This paper examines the impact of urban policy change through an attention to shifting feelings about time and place among those affected by such changes. The focus is the shift from 'Neighbourhood Renewal' under the UK Labour Government (1997-2010) to 'localism' under the Conservative Coalition Government (2010-2015), as part of its programme of austerity. The article draws on longitudinal research with policy officials and residentactivists in two neighbourhoods in one UK city, and examines their narratives about policy change and wider shifting feelings about time and place. From an official perspective, discourses and practices of localism were embraced to an extent, but uncertainty was also present. From the perspective of resident-activists, the changes in policy were experienced as a loss of past services and support, senses of pessimism about the future, and fragmenting and inequitable trajectories for different localities. Temporalities of crisis were also apparent in responding to the material needs of residents undergoing deepening poverty. The failure of the localism discourse to provide everyday meaning can be seen as an example of the incoherent and fragmented nature of contemporary austerity urban governance. A time-space perspective, in particular focusing on how both policy actors and citizens use narrative to organise their spatial and temporal experiences, therefore offers resources for the wider analysis of urban governance.
\end{abstract}

Keywords: austerity, temporality, governance, localism, narrative. 


\section{Introduction: searching for policy in a crisis era}

This paper examines how changes in urban policy and governance shape citizens' lives, via a focus on experiential dimensions of time and space. It draws on research in two neighbourhoods in one UK city, undertaken during 2004-5 and again in 2013-14. This embodied experience of returning to communities after eight years forms one of the temporalities that shapes my analysis. I was there to research the effects of economic and political change, including shifts from a welfare-orientated UK Labour government (19972010), to a Conservative-Coalition one (2010-2015) whose social policy programme oversaw large reductions in public spending. Much was different about the second round of research. On my return, other than seeing the impacts of austerity and cuts, it was much harder to detect in what ways policy shaped what was actually happening in the neighbourhoods. As Matthews (2012) observes in relation to urban 'neighbourhood regeneration' in Scotland, previous rounds of policy had identifiable empirical referents, including material spaces (such as new houses) and interventions which sought to bring about change. For all the problematics of these programmes, there was a sense that 'something..had occurred' (Matthews, 2012: 157) that had a purchase on everyday experiences.

However, in what has been referred to as an era of 'crisis social policy' (Hancock et al, 2012) contemporary UK Conservative policy discourses seem to have a less direct relationship with times and spaces. This is partly a question of austerity, and the 'hollowing out' of a state which simply does less. However, it can also be seen as a qualitative shift in the nature of policy-making and governance, and thus the ways that the state is experienced by citizens. The current era in the UK is characterised by policy terms which, whilst powerful, have a diffuse quality. For example, notions of 'co-production' and 'personalisation' (Needham, 2011) have been invoked as designating a new approach to care services, negotiated between professionals and users. Another term which falls into this category is 'localism', which forms the focus of this paper. These terms shape imaginings, possibilities and narratives, as much as signal actions. Such terms function through a logic of invitation (Allen, 2006), suggesting that policy actors and citizens see their actions as part of such categories, categories which nonetheless re-direct attention and close down other possibilities by degree. As the paper will argue, these terms narrate certain versions of past and present in relation to places. Yet citizens and policy actors are not necessarily seduced by such narratives. 


\section{Localism, austerity and neoliberalism}

'Localism' as recently invoked within UK urban policy, signals a renewed interest in the neighbourhood or 'the local' as a site of services and social action, away from discourses of 'the big state' (Lowndes and Pratchett, 2012). Wills (2016: 9) offers the following definition:

Localism is about engaging local people in local civic life, but less obviously, it is also about the nature and purposes of the central state.

As she points out, localism within UK policy debates did not begin with the advent of the UK 2010 Conservative Coalition government, and instead was redefined at that particular moment. The proceeding UK Labour government (1997-2010) had also made a focus on the 'local' a key aspect of public policy, particularly urban social policy aimed at deprived neighbourhoods. Indeed 'neighbourhood' and 'community' featured strongly within Labour policy at that time, within a broadly 'communitarian' or 'third way' approach to policy, that claimed to empower marginalised communities as the state nonetheless withdrew from wider forms of intervention (Imrie and Raco 2003). Urban policy programmes such as the New Deal for Communities involved local residents in partnership working on programmes concerned with both physical 'regeneration' and local investment in employment, health and other services (Lupton, 2003). New neighbourhood workers were employed to engage local people in these projects. The programmes were fraught with difficulties, relying as they did on instrumental notions of 'community' (Newman, 2001. Nonetheless, as will become clear, 
at a straightforward level the programmes involved some new resources for disadvantaged neighbourhoods.

Aspects of the localism agenda under the UK Coalition government (2010-2015) can be seen as a critical response to this local 'empowerment' under Labour, although there are significant continuities in the ultimate shifting of responsibilities for inequality onto communities themselves. Nonetheless, the Coalition approach presented itself as a break from the past, promising less government, within a rhetoric of removing 'red tape' and 'freeing up' communities. As such the Coalition government discourse involves setting out a particular narrative around both the past and future of relationships between citizens and the state.

This is a UK government policy definition of localism (DCLG, 2010: 3):

- To lift the burden of bureaucracy — by removing the cost and control of unnecessary red tape and regulation, whose effect is to restrict local action;

- To empower communities to do things their way - by creating rights for people to get involved with, and direct the development of, their communities;

- To diversify the supply of public services - by ending public sector monopolies, ensuring a level playing field for all suppliers, giving people more choice and a better standard of service;

Of particular interest here are the ways that these (potentially conflicting) aims narrate visions of the past and the future. The past is associated with an oppressive state, of 'red tape', and 'public sector monopolies' which have a stifling effect on communities, 'crowding out' other forms of provision. Instead a 'freeing' of bureaucracy is promised, enabling new 'rights' and 'choices' for citizens, within a broadly neoliberal discourse, in which 'the presence of the future' (Anderson, 2010) shapes the politics of the present. Such a discourse also has a set of geographies, framing a vision of autonomous communities, directed by the efforts of citizens.

As already indicated, this new approach largely signalled an invitation rather than a concrete set of actions at a local level. As will be explored, whilst residents in the neighbourhoods were aware of 'Neighbourhood Renewal' during the Labour government, the era of 'localism' was much less apparent. Localism for the Coalition government in concrete terms involved designating new 'rights' which communities could choose to take up. These were 


\section{Time, space and policy: foregrounding narratives}

The research therefore set out to understand how the shift from 'neighbourhood renewal' to 'localism' had been experienced by officials and residents in neighbourhoods in one UK city. Whilst the research was initially framed by questions of space, scale and locality, the focus on experiences of time and temporality developed in response to interview data generated. Indeed whilst it was the experiences of the present which was the intended focus of my research project, it was notable that temporalities of the past and future were increasingly pressing within the experiences of the research participants (see Knight and Stewart 2016).

In linking a time-space perspective to the experiences of my research participants undergoing political, economic and social change, I have foregrounded the idea of narrative or story, as a 
way of organising meanings of time and space. 'Narratives' have been used within social science analysis extensively, more recently moving beyond a discursive approach to take in space, place and embodiment (Heavey, 2018). As Cameron (2012) argues, narratives and stories involve questions of language and speech, but also affect, emotion, and relationality. Narratives position position the story-teller both in time and space.

In relation to place, urban policy and governance has always involved competing imaginaries and narratives of place - often thought about in terms of the re-branding of high profile central city places where there are clear stakes in terms of the attraction of investment (eg Wallace, 2015). The ways in which urban policy symbolically constructs poorer communities has been less researched, although Crossley (2017) traces the 'imagined geographies of poverty', which have powerful effects in shaping interventions. In the case of discursive shifts such as 'co-production' and 'localism', it is not just places themselves that are being re-imagined, but the relationships between different tiers of government and communities, in other words the relations which make up places - the responsibilities and flows of power (Massey 2004),. How places are seen in policy terms also intertwines with how residents see and experience their own emplaced identities (Lombard 2013). Deprived communities, often areas of social housing or 'housing estates' in a UK context can be thought of as symbolically 'over-determined' for both government and for residents, carrying a weight of imaginings and emotions including stigma, pride and ambivalence (Jupp, 2013). These ambivalences may be particularly acute in post-industrial communities where the relations of power and practices that gave those places their identity have been lost, and the future feels uncertain (Bennett 2013).

Considering place in policy therefore inevitably brings temporality into view. A starting point for analysis of temporalities has been the different dimensions of time: on the one hand time a set of rhythmns and tempos that order everyday life in material ways, but also a set of normative discourses that are part of the organisation of social, political and economic life (Bryson 2007). As Cooper (2013: 33) writes, policy discourses (such as that related to localism) 'fold in particular narratives of the past and present'. Policy narratives seek to tie the past and the future to a particular analysis of the present, for example in relation to links between citizens and government. However, research in cultural geography (eg Till, 2012) and feminist sociology (eg Bryson, 2007) has drawn attention to the co-existing temporalities which contest such narratives of governance. Such temporalities may be tied up with 
different ways of narrating experience, for example around the lifecourse, work and care. Importantly, diverse temporalities will be linked to different forms of power.

Indeed, whilst the production of spatial inequalities under neoliberalism has been well documented, it is only recently that temporal inequalities have been focused on (Sharma 2014). Sharma (ibid) calls for attention to 'power-chonographies' to unpick the unequal values assigned to different groups' experiences of time. Similarly, Agbiboa (2019) draws attention to conflict between 'capitalist' vs 'everyday' times, including who has the power to imagine different futures, and Raco et al (2008) analyse the disjunctures between 'official imaginaries' of time and place within urban development projects and more everyday experiences. Other research has focused on time as well as space in relation to the category of 'community' (eg Bastian 2011). Such an approach therefore has the potential to bring into focus the inequalities and ruptures between policy and governance on the one hand, and everyday life and experience of times and spaces on the other.

Policy discourses and narratives thus relate to experiences of the present, versions of the past, but also anticipation of the future. In relation to 'austerity', while the term calls up certain visions of a past moment in UK history post WW2 (Brammall, 2013), it may be senses of the future that are particularly affected (Anderson and Adey, 2012; Knight and Stewart 2016). Horton (2016) points out that young people occupy a vivid role in fears about the future, because of their embodied presence as adults-in-becoming. In interviews with youth workers and services users, he draws attention to the refrain of 'the current climate' which shapes feelings and narratives about the future, the 'anticipatory anxieties' that had: 'impacted substantially on friendships, working practices, service provision.' (ibid: 364 ).

The analysis that follows considers the narratives that are used to understand the past, present and future of particular places. A related term to narrative is that of 'trajectories'. Although this term was not necessarily used by research participants, for both the residents and officials, the question of the future of the neighbourhoods, the kinds of 'pathways' they were on, and whether they would 'get better' or 'become worse', was an ever present one. These imagined trajectories therefore linked questions of place with questions of the past, present and future, that might be experienced as the 'intergenerational inheritances' (MacLeavy et al 2018) of a place. The notion of 'cycles' was also invoked, both by residents and officials: were the communities in a cycle of decline or regeneration? Were they moving 'forwards' or 
'backwards'? Another key question was how the 'trajectory' of a particular neighbourhood related to others; was a certain area being 'left behind' whilst life in others 'improved'?

\section{Introducing research: methods and fieldwork sites.}

The research was undertaken during 2013-2014, and was part of a wider project that involved revisiting two UK local authority areas where I had undertaken research on community projects under the previous government. The research sought to understand how the shift from an era of intensive neighbourhood policy to localism was experienced, against a background of austerity and wider economic and political change. For the new project I interviewed twelve local authority officials and both professionals and residents working on projects at a neighbourhood level. In relation to the two small community groups which form the focus of this paper, I undertook two group discussions and participant observation at three sets of activities, as well as a depth interview with two key actors, discussed below.

For the purposes of this paper, I focus on just one of the sites, a post-industrial city in the Midlands, UK. Between 2004-2006 I spent extensive periods of time in two neighbourhoods in this city, that I refer to as Riverlands and Southfields, for a previous research project. Both these neighbourhoods could be classified as 'disadvantaged' and were areas of social housing on the outskirts of the city. Whilst Southfields was a larger area, and closer to the city centre, they shared many similar characteristics. Within these neighbourhoods, my research focus was two small community groups. These were resident-led, directed by two women, Sandra, the chair of the Riverlands group, and Jill, the chair of the Southfields group (both these names are pseudonyms). At the time of my original research, they had both been based in 'community houses', ordinary houses given over to the groups by the council. The community groups ran a range of social projects on the estates, often focused on different age groups and especially young people, as well as being involved in redeveloping public spaces (for example a new children's playground and community gardens), and campaigning for more resources for the localities. At the time of my original research, both groups' work was supported, and to some extent resourced, by a network of officials, programmes and partnerships that formed part of the Labour government's programme of neighbourhood policy. 


\section{Governing the contested time-spaces of localism}

Discussing localism with Claire involved wider questions of what it now meant to be in local government in a context of 'austerity'. The resources available to local authorities, and especially those in economically deprived areas, has fallen dramatically since 2010 (Hastings et al 2017) . As Horton (2016) notes, this context formed an all-pervasive background 'noise' that permeated narratives of the past and future. As Clarke (2013) has pointed out, a narrative of the past as 'irresponsible' seems to have become part of a new 'truth' within policy discourses at various levels that, 'you can't solve problems by throwing money at them'. Claire spoke about the 'mistakes' made in spending 'too much money' in deprived communities, within a sense that this had encouraged overly dependent relationships between the local state and communities. 
The financing is some of it, not everything. I think we became too hung up probably in the past on it has to be funded, but some things... you know the money does give a kick start.

This quote nonetheless conveys unease about how important 'the money' had been in supporting community activity in the past. The discourse of 'localism' as outlined, of a new era in which communities and citizens became less dependent on the local state, was being accepted as a new narrative of place and time in uncertain ways. On the one hand, in the city, 'localism' and 'locality' had become key terms in new structures and ways of working. A 'localities framework' had shaped a restructure of council services around three large spatial areas, yet this framework appeared to primarily involve the loss of posts and services. Claire reported that their localism approach was about 'a lack of duplication and replication' signalling both cuts to service and staff and also a discourse about better customer service.

...in order to do that it was no good having a Libraries Manager anymore, we needed Locality Managers so they moved to a much more integrated approach, so for example the Libraries Manager is now the Central Locality Manager overseeing the development of a range of services

This more 'integrated approach' spoke of a future council that was 'leaner' and less wasteful, rather than the cumbersome bureaucracy which was seen to have created too much dependence in the past. In relation to neighbourhood support, this new landscape involved a drastic reduction in the previous infrastructure of neighbourhood workers at a range of scales. Claire talked about this very reduced service (three community workers, replacing approximately 30 at the time of my earlier research):

Their role now...it's more signposting and working alongside trying to create the autonomy in organisations. .. I would say the work now is very much about trying to encourage more independence. We can't any longer do the.. I don't know whether hand-holding is the right word but we don't any longer do that kind of support for those communities that we would have done in the past

This quote begins with the a narrative of 'localism' ('trying to create autonomy', 'encourage more independence'), through perjorative notions of 'hand-holding', but ending with a more straightforward acceptance that they can no longer provide 'support' to communities. Both 
Claire and others appeared caught between feeling compelled to provide a positive narrative of change and yet feeling aware of the problematics of localism as a narrative to justify austerity cuts and essentially abandon deprived urban communities.

\section{Trajectories of decline and fragmenting futures}

As can be seen, the interview with Claire highlighted the difficulties of narrating the policy changes that she was working under. Sandra and Jill, as figureheads for their community groups, were also often tasked with narrating the trajectories of their communities within time and space, for example during council meetings. Yet the stories they were now telling were much more pessimistic than in my previous research, when they had often spoken about community spirit and optimism (Jupp 2013).

Indeed, whilst official perspectives suggested an uneasiness about the shift to 'localism' and its impact on neighbourhoods, the perspectives of Sandra and Jill were more stark around a dramatic experience of loss in relation to the neighbourhood support and funding that had been available to them. These losses were felt to have had material impacts on their work, within a context of growing poverty as well as benefit changes and cuts in already disadvantaged neighbourhoods. The current moment was also related to a marked divergence of 'trajectories' within the two neighbourhoods, as explained below.

A focus for both groups had been engaging with perceived and material problems associated with young people and neighbourhood spaces, linked to low level disturbances, so-called 'anti-social behaviour' or 'gangs' (both groups were critical of these terms). As already mentioned, feelings linked to young people could be seen as playing a particularly potent role in narratives of time and space in the neighbourhoods (Horton 2016). Both groups had, in the past when more resources had been available to them, run a range of creative and sustained projects with both young people and older people to try and tackle the negative effects of inter-generational tensions The following quote encapsulates a sense of narrative as disrupted, as the visions of the future held in the past seemed to be rupturing (Knight and Stewart 2016), and a feeling of loss and of 'going backwards' permeates, linked to the 'cycles' already mentioned: 
Sandra: (In the past..) there were large groups hanging about the streets and the people in the houses were intimidated, so we had to do a lot of inter-generational work to ease those barriers, and it got an awful lot better, as we had the Youth Clubs, we had all these projects, we had the Play Club and everything else. We now don't have a Youth Club, because we don't have the facilities to have a Youth Club. It's resurfacing, those issues are coming back, and you can see the next generation, they're going to have the same issues that the last one did.

Jill: I do feel quite sad for our area in respect as I feel we're going back... we're taking steps back instead of steps forward

Sandra: Yeah, it is regressing

Jill: I feel that we're starting completely from scratch again.

Whilst both Jill and Sandra had always been critical about the neighbourhood programmes under the Labour government, they spoke about the difference that the embodied presence of neighbourhood support workers had made in the past, compared to the current situation under 'localism':

I wouldn't say there's any real support network for any community groups at the minute. There's something called a Community Matters Group that consists of three people who cover the whole of city basically [the Localities framework], but obviously you can't get support. All the support's been withdrawn, so Neighbourhood Renewal, the Area Implementation Teams they've all gone, so there is nothing left (Sandra).

These losses were also experienced as a sense of 'going backwards', or 'going full circle', returning to a situation before the investment which came with the Labour government :

See for us in the early days this is how it was. This is how it was. When we first set up as an residents association this is how it was and then they started Play Services, they started Neighbourhood Services, so really I feel you've gone full circle now (Jill).

Localism was therefore experienced as loss, but also often confusing shifts in governance arrangements and fragmenting public services. As Hitchen (2017) has argued, narratives of localism and the wider language of 'service improvements' may obscure the material losses 
of austerity, rendering it harder for them to make sense of the changes they are subject to. For example, on Riverlands, the loss of facilities for a youth club was linked to the loss of the relationship that the community group had developed with the local secondary school, who had let them host the youth club on the school site. This school had since become part of a chain of 'academy' schools that bring together private money and public services, and had severed ties with the community group according to Sandra: 'now it is the academy.. there is not relationship whatsoever, none'. This example highlights the ways that 'localism', through drawing (non local and commercial) 'new providers' into the field of public service delivery, actually has the potential to sever local relationships and identifications (Clayton et al 2016), and create affective disconnect and distance.

Relatedly, such a reconfiguring of neighbourhood governance through a withdrawal of public investment and the growing prominence of private investment (Penny 2016), had also had a marked impact on the overall 'trajectories' of the community groups and neighbourhoods. Whilst both neighbourhoods had experienced the loss of infrastructures of neighbourhood policy, as well as the overall impacts of growing poverty, Southfields had, since my previous fieldwork, attracted private sector investment in housing, and, through planning gain and the involvement of a housing association, investment in community buildings and open spaces. The estate had been part of a scheme (initiated under the Labour government) to lever new investment into areas that had potential for 'housing market renewal' (Webb 2010), based essentially on the neighbourhood's position in relation to the city centre.

Indeed, when returning to Southfields after seven years, new housing, and a number of new community projects including a cafe operating as a 'social enterprise', meant that walking around it felt quite different. A derelict shopping centre, previously described as 'Little Beirut,' had been transformed, including a new glass, steel and coloured render community 'Hub' building, which the Southfields community group had been instrumental in planning and were now key partners in managing. The interview with Jill and Sandra took place in the Hub, which was bright and modern, and very different from the community houses they had both previously been in. Whilst operating within a framework of overall service reductions, the Community Hub had nonetheless become a focal point for local services, including for example, a new police post in the building. This made the joint interview uncomfortable at times, as the different trajectories of the neighbourhoods and groups were materially apparent. For example, Sandra mentioned that they no longer had a police officer in their neighbourhood: 
Sandra: We've got another difficulty with police cuts, we don't have a neighbourhood bobby anymore.

Jill: Don't you?

Sandra: No, we haven't got one.

Jill : I don't feel guilty because we've worked so hard for it. There have been times, Sandra, when the boot has been on the other foot, hasn't it?

Sandra: Things change

Jill: In ten years time, you could come and speak to us and things could be completely different

Sandra: What you do is you adapt to the situation you're in at that moment in time.

This is quite a poignant interaction and one of a number of moments in the interview where the different and inequitable presents (and futures) of the neighbourhoods were brought into sharp focus. When I first visited the neighbourhoods, in both the look and feel of the areas and within the deprivation statistics, Southfields felt relatively more deprived than Riverlands. Seven years later that situation had been reversed. At both this and other points in the interview there was a sense that Jill did feel guilty about the situation where, without market-led investment, Riverlands had been fully exposed to the impacts of austerity cuts. Indeed whilst under 'Neighbourhood Renewal' there was some desire to allocate resources on the basis of need (although the housing market renewal programme was also initiated under Labour), the new era of 'localism' seems blind to inequality, in a discourse that 'constructs places in isolation (and) avoids an engagement with the marked inequalities that exist within and between places' (Featherstone et al, 2012: 3).

Of course, a market-based welfare economy also depends on a viable market at whatever scale. Both community groups had been supported or perhaps coerced into becoming 'social enterprises', in order, in theory, to move away from an era of 'hand-holding'and become self-sustaining within the localism narrative. In relation to the Southfields group, this meant leasing the Hub building to other 'service providers' so that it could become financially self sufficient and not reliant on public funding. However, the service providers themselves were public services or reliant on public services, and therefore austerity cuts de-stabilised these 
plans. For example, there had been plans for a library to be based in the Hub. but there had been huge cuts to library services:

The Library now is run completely by volunteers with the support of Library services... that's another rental income we'll lose this year, and that's another $£ 8,000$ a year that we've got to find from somewhere else so we take two steps forward and always taking four steps back (Jill)

There had been similar experiences with other service providers, meaning that many of the spaces in the (large) new building were empty whilst I was doing the interview, and a sense of fragility about its future and sustainability pervaded, with Jill's ability to construct a narrative about it uncertain.

\section{The time-spaces of crisis}

A sense of fragmentation and inequality in relation to the trajectories of different neighbourhoods can be seen as one of its empirical markers of localism (Williams et al 2014). Unlike Southfields, Riverlands seemed to have been exposed to the worst impacts of austerity and deepening poverty, and this was evident in the feel of the neighbourhood on my return visits. Sandra described a community in social and economic crisis, and this meant that in terms of temporality, short term needs had become dominant and undermined the group's previous investments in the future, in what Knight and Stewart (2016) analyse as a 'slowing down of the present' under austerity.

The agenda used to be, say traffic calming, people were worried about kids getting knocked over, now it's just, there's not going to be food in bellies... the social and economic situation of households now is so bad, we can't really address anything else.

The group were now focused, for example, on children going hungry over the summer holidays.

Over the summer, there are real issues with hunger as the kids won't be getting the free school meals you see, six weeks.. it doesn't bear thinking about. 
This focus on the short-term present as the dominant temporality and the experiential realities of supporting families in dire material need, meant that the group's supposed aim of becoming a self-sustaining 'social enterprise', and charging for their 'services' had quickly become unviable.

All activities with kids we give out food, we charge 60p per head for playgroup but for that we have to pay $£ 19$ per evening to the church hall. Then some people haven’t got $60 \mathrm{p}$, I'm not gonna turn them away am I. .. so the whole thing just doesn't add up

In response to these issues of hunger, the group was now running a food redistribution project working with an organisation that collected excess food on a regional basis. Again this was supposed to be charged for, and to be a 'self-sustaining' project. However, Sandra said that they struggled to ask residents for money for the food, and were funding it through other activities including running events for other community groups.

The problem with ours, the food redistribution project is a sticking plaster. . It will alleviate an immediate need and that's all it does, and a lot of people that come in haven't got $£ 2$ to pay for a food parcel, so you're having to give it away, which continually adds pressure on our group to fund raise and subsidise that project, that need, so we do events all over the city... Now the majority of it would go directly on the food redistribution project. There's very little left for any other projects and that's the one project we cannot allow to fail, it has to continue.

The time-spaces of crisis therefore involved responding to immediate needs around hunger and wider issues of poverty, yet the group were still being pushed to narrate their activities within a language of self-sufficiency and independence promoted by the localism discourse. This created an irreconcilable sense of temporal conflict (Sharma 2014). Sandra was painfully aware of the demands of these discourses of longer term self-sufficiency, as the quote below shows, at just the time when residents needed short term basic forms of welfare more than ever:

Like I said, it's a sticking plaster and it's never going to achieve the outcomes of making somebody self sufficient. You're not going to get to the stage where they don't need that service. Until they get a job, until the benefits are paid properly, until they're not ill anymore, until the families are grown up, there are so many things that 
impact on why people can't feed their families that we're never going to solve that, so we're not going to reach those outcomes.

The 'sticking plaster' phrase was used by both groups as an analogy for operating within this context of responding to embodied and painful experiences of poverty with a short-term fix. The temporalities of crisis relate also to a wider crisis in social relations in the neighbourhood. Sandra reported that the anger circulating within the community because of the loss of services and wider experiences of poverty was now being directed at the community group themselves.

As more and more things are withdrawn from people they get despondent, disheartened and apathetic. Now they will either walk away, or they will become angry, and expect us to provide all the things that were provided by the statutory services but we're not there to do.

Whilst localism is supposed to act as a catalyst for community action, experiences of austerity, as Hitchen (2016) writes, 'fatigue the body' and undermine community cohesion and action, as well as positive hope for the future (Pain, 2019).

\section{Geographies going on?}

Despite this increasing 'affective distance' (Clayton et al 2016) and disconnect between the temporalities and narratives proposed in policy and the temporalities of lived experience, time and space do also simply 'go on' (Horton, 2016), with different futures unfolding in mundane and sometimes hopeful ways (Agbiboa 2019). Although the focus of this article has been losses and fragmentation associated with policy change, the depth interview with Sandra and Jill was also infused with accounts of successful trajectories, often around the volunteers themselves, and within the lifecourses of young people they had worked with. Jill recounted a recent encounter in a local supermarket with a young person with whom the group had worked previously:

'this was one of those kids who was getting in trouble at school all the time, he was close to being expelled.. . and he just said, 'hi, how are you?' and I looked at him, and I thought, "is that the person we started with all those years ago?" And yes, it obviously wasn't one thing that had made a difference to their life, but those small 
steps and someone actually believing in them, and that it wasn't all bad that they were doing...just them small things, that small encouragement off somebody.'

This sense of small scale changes bubbling below the surface, that might only become visible in the long term, denotes a very different temporal orientation to that imagined by discourses of localism, instead connecting with relations and acts of care (Bryson, 2007). Sandra also gave examples of how the work of the group went on, a persistent forward motion, however fragile. When she had told me about the loss of the facilities at the high school for the youth clubs, she mentioned that they had started running activities outside

..so we lost all those facilities. We didn't let that stop, we delivered projects in open space, whether it be overgrown doesn't matter, you know if the grass is four foot high you can go bug hunting. If its cut down nicely you can play cricket and ball games, it doesn't matter there's going to be some sort of green space somewhere that can be used, which is what we did.

During the period of fieldwork with the community groups I joined in on a summer holiday 'bug hunting' session, when a crowd of local children and parents joined volunteers on a patch of wasteland at the edge of the estate - searching for creepy crawlies in the long grass, pond-dipping for water boatmen in the brook and modelling hedgehogs from clay and twigs. It was a happy sunny afternoon of small pleasures and triumphs.

This is not to overstate the power of these temporary and contingent moments in the face of the powerful political and economic changes that were impacting on the communities. Nonetheless, both examples point to divergent time-spaces which might be either longer or shorter term than those imagined within policy - growing up, care and the lifecourse, or the rhythmns of a summer afternoon.

\section{Conclusions}

This paper has demonstrated how temporality how can been viewed as a contested aspect of governance, and how temporality is connected to feelings and emotions, identifications and imaginaries (Jupp et al 2016). Adopting a time-space perspective, and analysing the narratives used by policy actors and citizens, enables a focus on how urban policy change feels (Pain 2019), and how different this might be from official discourses. This is 
particularly important in the face of seemingly consensual policy terms such as 'localism'. Indeed, contemporary policy has been discussed via notions of the 'post-political' (Nolan and Featherstone, 2015), an era in which conflict has been sidelined through discourses that appear to promise empowerment to citizens but essentially promote a neoliberal project. However, as Nolan and Featherstone (2015) argue, any 'post-political' settlement can only ever be partial: a time-space perspective allows for the ruptures and uneasiness around this settlement to be exposed, the ways that policy discourses fail.

As the article has shown, the notion of localism seeks to organise and narrate time and space. This paper has demonstrated the failures of the localism narrative, through a focus on rupture, fragmentation and conflict. Localism was experienced primarily as loss, often obscured within new governance arrangements and restructuring, as well as fragmentation and a divergence within the trajectories of communities, tied to increased exposure to market-led investment. Whilst localism discourses and practices encouraged small community groups and citizens to set out on a path of 'self-sufficiency' and a future away from 'dependence' on the state, the reality of community work, at least in one of the neighbourhods, had become increasingly about providing immediate support around poverty and hunger.

Within this context, rather than attending critically to its use, it is perhaps more pressing to consider why 'localism' continues to be taken up by local government officials at all. One way to understand this is the absence of an alternative narrative about the future: 'localism' suggests a meaningful trajectory rather than local governance being reduced to managing cuts. The politics of austerity is such that UK local authorities must both manage budget cuts and retain local electoral support (Penny, 2016). This then means that local communities are left to navigate this increasingly stark dissonance between policy narratives and temporalities and everyday experience.

The lens of temporality and narrative from the perspective of citizens also provides a different perspective on previous policy regimes, in this case the 'New' Labour government's neighbourhood policy. Whilst this policy did bring resources of various kinds into the neighbourhoods, in other ways they set the broader neoliberal economic and political direction of travel that was continued under the 'localism' agenda. The residents I worked with often criticala of the complex partnerships in their neighbourhoods during that era that often seemed to achieve little. Yet, they did appreciate the embodied presence of neighbourhood workers who did not necessarily follow the approaches of the programmes 
(Jupp, 2013), and provided practical forms of help and signposting to other services. As Sandra said, 'in the past, if you needed something, there was someone you could ask how to go about it, someone would help you'. Austerity localism has involved the local state completely withdrawing from various aspects of people's lives in communities.

This loss of embodied and relational understanding between workers and communities can only lead to more affective distancing and divergence between policy discoureses and lived experience. Ultimately a new progressive and expansive welfare settlement is needed that offers convincing narratives of past, present and future, and that residents of marginalised communities can place themselves within. Until then research -and activism - is needed that can critically unpick the stories that contemporary urban policy seeks to tell. 


\section{References}

Agbiboa D. E. (2019) The manipulations of time: On the temporal embeddedness of urban insecurity. Urban Studies 56(4): 836-851.

Allen J (2006) Ambient power: Berlin's Potsdamer Platz and the seductive logic of public spaces. Urban Studies 43 (2): 441-455.

Anderson B (2010) Preemption, precaution and preparedness: Anticipatory action and future geographies. Progress in Human Geography 34 (6): 777-798.

Anderson B and Adey P (2012), Future geographies, Environment and Planning A 44 (7): 15291535.

Bastian M (2011). The contradictory simultaneity of being with others: Exploring concepts of time and community in the work of Gloria Anzaldúa. Feminist Review 97 (1): 151-167.

Bennett K (2013) Emotion and place promotion: passionate about a former coalfield. Emotion, space and society 8: 1-10.

Blanco I, Griggs S and Sullivan H (2014) Situating the local in the neoliberalisation and transformation of urban governance. Urban Studies 51 (15): 3129-3146.

Bramall R (2013), The cultural politics of austerity: Past and present in austere times, New York: Springer.

Bryson V (2007) Gender and the politics of time: Feminist theory and contemporary debates. Bristol: Policy Press.

Cameron, E. (2012). New geographies of story and storytelling. Progress in Human Geography, 36(5), 573-592.

Clarke (2013) Governing the Social in an Age of Austerity. Public Lecture, Centre for Citizenship, Identities and Governance seminar series, The Open University, May 2013 
Clayton, J., Donovan, C., \& Merchant, J. (2016). Distancing and limited resourcefulness: Third sector service provision under austerity localism in the north east of England. Urban Studies, 53(4), 723-740

Cooper D (2013) Time against time: Normative temporalities and the failure of community labour in Local Exchange Trading Schemes. Time \& Society 22 (1): 31-54.

Crossley S (2017) In their place: The imagined geographies of poverty. London: Pluto Press.

Dagdeviren H, Donogue M and Wearmouth A (2019) When rhetoric does not translate to reality: Hardship, empowerment and the third sector in austerity localism. The Sociological Review. 67 (1) $143-160$.

Department of Communities and Local Government (2010) Decentralisation and the Localism Bill: an essential guide. London: HM Government.

Department of Communities and Local Government (2011) Localism Act 2011: overview. London: HM Government.

Featherstone D et al (2012) Progressive localism and the construction of political alternatives. Transactions of the Institute of British Geographers. 37 (2): 177-182.

Hancock L, Mooney G and Neal S (2012) Crisis social policy and the resilience of the concept of community. Critical Social Policy, 32(3): 343-364.

Hastings, A., Bailey, N., Bramley, G., \& Gannon, M. (2017). Austerity urbanism in England: The 'regressive redistribution' of local government services and the impact on the poor and marginalised. Environment and Planning A, 49(9), 2007-2024.

Heavey, E. (2018). 'If I can walk that far': space and embodiment in stories of illness and recovery. Sociology of health \& illness, 40(6), 1005-1018.

Hitchen E (2016) Living and feeling the Austere New Formations 87: 102-118.

Hitchen E (2017) The Cut as Transformation, paper at Nordic Geographers Meeting, June, Stockholm

Horton J (2016) Anticipating service withdrawal: young people in spaces of neoliberalisation, austerity and economic crisis. Transactions of the Institute of British Geographers, 41 (4): 349-362. 
Imrie, R., \& Raco, M. (Eds.). (2003). Urban renaissance?: New Labour, community and urban policy. Policy Press.

Jupp, E., Pykett, J., \& Smith, F. M. (Eds.). (2016). Emotional states: Sites and spaces of affective governance. London: Taylor \& Francis.

Jupp, E. (2013). 'I feel more at home here than in my own community': Approaching the emotional geographies of neighbourhood policy. Critical Social Policy, 33(3): 532-553.

Knight, D. M and Stewart, C. (2016). Ethnographies of austerity: temporality, crisis and affect in Southern Europe. History and Anthropology, 27(1): 1-18.

Lombard M (2013). 'Struggling, suffering, hoping, waiting: Perceptions of temporality in two informal neighbourhoods in Mexico', Environment and Planning D: Society and Space. 31.5: 813-829.

Lowndes V and Pratchett L (2012) Local governance under the coalition government: Austerity, localism and the 'Big Society'. Local government studies 38 (1): 21-40.

Lupton R (2003) Poverty Street: The dynamics of neighbourhood decline and renewal. Bristol: Policy Press

MacLeavy, J., \& Manley, D. (2018). (Re) discovering the lost middle: intergenerational inheritances and economic inequality in urban and regional research. Regional Studies, 52(10), 14351446.

Massey D (2004) Geographies of responsibility. Geografiska Annaler: Series B, Human Geography $86(1): 5-18$.

Matthews P (2012) 'From area-based initiatives to strategic partnerships: have we lost the meaning of regeneration?' Environment and Planning C: Government and Policy 30 (1) 147-161.

Needham C (2011) Personalization: From Story-line to Practice. Social policy \& administration 45 (1): $54-68$. 
Newman J (2001) Modernizing governance: New Labour, policy and society. London: Sage.

Newman J (2014) Landscapes of antagonism: Local governance, neoliberalism and austerity’, Urban Studies. 51 (15): 3290-3305.

Nolan LJ and Featherstone D (2015) Contentious politics in austere times. Geography compass 9 (6): 351-361.

Pain, R. (2019). Chronic urban trauma: The slow violence of housing dispossession. Urban Studies, 56(2): 385-400

Painter J (2012) The politics of the neighbour. Environment and Planning D: Society and Space 30 (3): $515-533$.

Penny J (2017) Between coercion and consent: the politics of 'Cooperative Governance' at a time of ‘Austerity Localism' in London. Urban Geography 38(9): 1352-1373.

Prior, J., \& Hubbard, P. (2017). Time, space, and the authorisation of sex premises in London and Sydney. Urban Studies, 54(3), 633-648.

Raco M, Henderson S, and Bowlby S (2008) Changing times, changing places: urban development and the politics of space-time. Environment and Planning A 40 (11): 2652-2673.

Sharma S (2014) In the meantime: Temporality and cultural politics. Durham, North Carolina: Duke University Press.

Till K (2012) Wounded cities: Memory-work and a place-based ethics of care. Political Geography 31 (1): 3-14.

Wallace A (2015) Gentrification Interrupted in Salford, UK: From New Deal to 'Limbo-Land' in a Contemporary Urban Periphery. Antipode 47(2): 517-538. 
Webb D (2010) Rethinking the role of markets in urban renewal: The housing market renewal initiative in England. Housing, Theory and Society 27 (4): 313-331.
Williams M, Goodwin, and Cloke P (2014) Neoliberalism, Big Society, and progressive localism. Environment and Planning A 46(12): 2798-2815;

Wills J (2016) Locating Localism: Statecraft, citizenship and democracy. Bristol: Policy Press. 